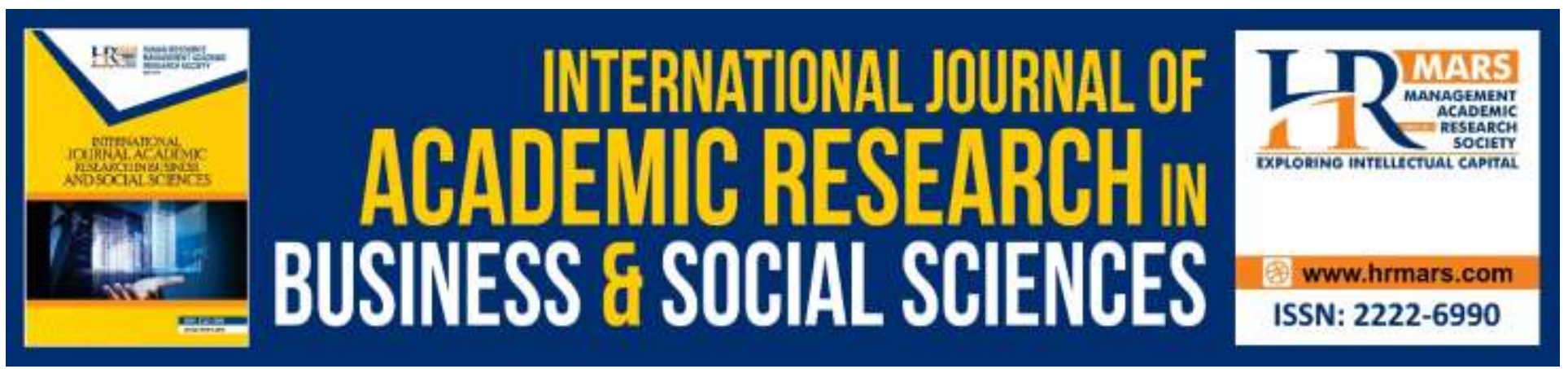

\title{
Primary School Teachers' Perceptions on the Integration of Interactive Whiteboard (IWB) during Reading Instructions
}

Kamini Karthigesu, Maslawati Mohamad

To Link this Article: http://dx.doi.org/10.6007/IJARBSS/v10-i2/6977

DOI:10.6007/IJARBSS/v10-i2/6977

Received: 20 January 2020, Revised: 01 February 2020, Accepted: 12 February 2020

Published Online: 27 February 2020

In-Text Citation: (Karthigesu \& Mohamad, 2020)

To Cite this Article: Karthigesu, K., \& Mohamad, M. (2020). Primary School Teachers' Perceptions on the Integration of Interactive Whiteboard (IWB) during Reading Instructions. International Journal of Academic Research in Business and Social Sciences, 10(2), 722-741.

Copyright: (C) 2020 The Author(s)

Published by Human Resource Management Academic Research Society (www.hrmars.com)

This article is published under the Creative Commons Attribution (CC BY 4.0) license. Anyone may reproduce, distribute, translate and create derivative works of this article (for both commercial and non-commercial purposes), subject to full attribution to the original publication and authors. The full terms of this license may be seen

at: http://creativecommons.org/licences/by/4.0/legalcode

Vol. 10, No. 2, 2020, Pg. 722 - 741

http://hrmars.com/index.php/pages/detail/IJARBSS

JOURNAL HOMEPAGE

Full Terms \& Conditions of access and use can be found at http://hrmars.com/index.php/pages/detail/publication-ethics 


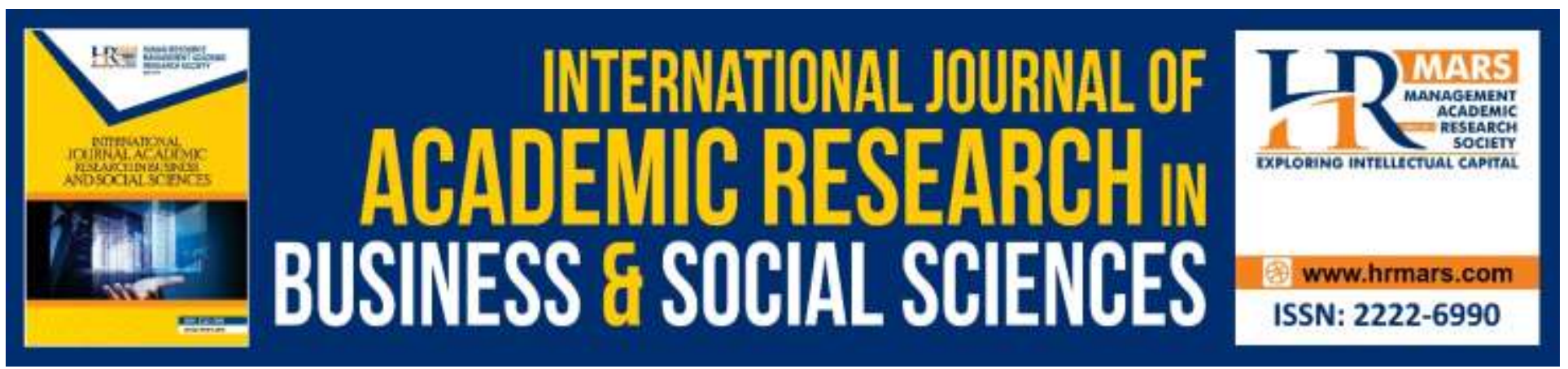

\title{
Primary School Teachers' Perceptions on the Integration of Interactive Whiteboard (IWB) during Reading Instructions
}

\author{
Kamini Karthigesu, Maslawati Mohamad \\ Faculty of Education, National University of Malaysia, Malaysia \\ Email: kaminikamzy@gmail.com, maslawati@ukm.edu.my
}

\begin{abstract}
Education scenario in Malaysia is constantly changing due to the demands of 21st century and Education 4.0, especially for technologically literate and critically thinking workforce. However, the current situation in ESL classrooms demonstrates lack of motivation among pupils specifically during reading comprehension lessons. Likewise, providing interesting yet exciting reading lessons has always been a challenge for teachers across the country. This study aims to explore the perceptions of teachers on the integration of Interactive Whiteboard (IWB) in reading comprehension lessons and how it could be implemented effectively in ESL classrooms. A qualitative case-study was carried out among 6 ESL teachers and 6 pupils who were chosen through purposive sampling. The individual teachers' interview and focus group interview were analysed using Burnard's 14 stages method of analysis along with the data triangulation of classroom observation field notes and document analysis. The findings indicate that teachers' have positive perceptions towards integrating IWB in ESL reading lessons such as increase in concentration, engagement and motivation to read. The integration of IWB was found to satisfy pupils' multiple intelligence with the implementation of various features. The implication of the study is that teachers need to be made aware of IWB' potential during the ESL reading lessons in particular since they are still at an initial stage of transmission from the conventional 'chalk and talk' teaching approach to integrating IWB for classroom teaching and learning purposes.
\end{abstract}

Keywords: Perceptions, English as a Second Language (ESL), Interactive Whiteboard (IWB), Reading Comprehension, Primary School Teachers

\section{Introduction}

Many changes are taking place in today's education scenario of Malaysia as a response towards Education 4.0 and $21^{\text {st }}$ century challenges. In order to ensure that only technologically literate and critically thinking workforce are joining the competitive global economy, it is essential that the current generation of pupils are nurtured with the $21^{\text {st }}$ century skills, attitude and thoughts across their learning processes. Hence, latest educational technologies and strategies are being 
vigorously adopted by teachers. Malaysian Education Blueprint 2013-2025 under Shift 7 has stated that incorporation of ICT in education allow for more customized learning. In this context, ICT could be utilized in various ways during instructional activities to promote self-paced, independent learning among pupils.

According to Sharmini et al. (2003); Khalid, Islam \& Ahmed (2019); Alzgool (2019), increasing pupils' responsibilities and participation towards reading may help to sustain effective learning. Nevertheless, one of the reading problems faced by pupils in ESL classroom is feeling less motivated to engage in classroom activities during reading comprehension lessons. This is particularly due to limited exposure to English language which could have resulted in poor reading comprehension skills. If left unresolved, this problem may hinder the pupils from mastering the language. It is indeed a great challenge to capture pupils' attention and engage them during reading comprehension lessons. This is because reading activities conducted in the class are most likely to be monotonous and repetitive. Teachers are also facing difficulties in adopting relevant teaching strategies which would fulfil the learning needs of all type of learners. As such, implementing interesting lessons alongside with utilization of appropriate technological tool has become the primary concern of ESL teachers. Technological revolution has become inevitable in many fields due to the varying demands of the new century (Simin \& Sani, 2015; Umrani, Ahmed \& Memon, 2015; Zin \& Ibrahim, 2020).

In regards to this, Interactive Whiteboard (IWB) is one of the latest advents which has been gaining popularity in education. IWB uses a variety of texts, big books, pictures, graphic, audio and moving images to capture pupils' attention during reading comprehension lessons. This technology is believed to be a good solution to problems faced by pupils to comprehend abstract words or phrases from ESL reading texts. Hence, this study is aimed at exploring the perception of teachers and pupils on integration of IWB in reading comprehension lessons and how it could be implemented effectively in ESL classrooms.

\section{Objectives of The Study}

The objectives of the study are as follows:

1.) To investigate the perceptions of English primary school teachers towards the integration of Interactive Whiteboard (IWB) during ESL reading comprehension lessons.

2.) To investigate the implementation of Interactive Whiteboard (IWB) by English primary school teachers in teaching ESL reading comprehension.

\section{Research Questions of The Study}

Based on the research objectives, the following are the research questions for the study. This paper discovered relevant answers for the following research questions:

1.) What are the English primary school teacher's perceptions towards the integration of Interactive Whiteboard (IWB) during ESL reading comprehension lessons?

2.) How does English primary school teachers implement Interactive Whiteboard (IWB) to teach

ESL reading comprehension lessons in the classroom?

\section{Literature Review}


INTERNATIONAL JOURNAL OF ACADEMIC RESEARCH IN BUSINESS AND SOCIAL SCIENCES Vol. 10, No. 2, Feb, 2020, E-ISSN: 2222-6990 @ 2020 HRMARS

\section{Reading Comprehension}

Reading requires students to actively cooperate with a text and try to comprehend its meaning (Alyousef, 2005). According to Klingner et al. (2007), reading comprehension is the process of constructing meaning to a text, which is achieved through word reading, word knowledge and fluency. Reading comprehension revolves around improving reading skills, grammar, vocabulary and reading enjoyment (Rahman \& Jameel 2011). Besides, reading comprehension helps to develop writing and linguistic competence of the reader.

\section{Problems in Teaching Reading Comprehension}

Young learners often face problems in reading. This could be due to their lower concentration capacity and lack of motivation to read texts for a long time. Without proper guidance and strategies to scaffold them, this problem may persist and ultimately result in poor reading skill. Pupils who are interested in reading generally have high intrinsic motivation. Due to many reasons, many of the young learners lack motivation to participate in reading lessons. They could simply read a text aloud without understanding its meaning and this is mainly caused by their poor reading comprehension skill.

One of the reasons for this is inappropriate technique or pedagogy used by English teachers in teaching reading to pupils. To make things worse, teachers seldom give adequate attention towards pupils who are weak in their basic language skill such as unable to recognise alphabets and pronounce words correctly. This will also discourage pupils to read. The current generation of pupils are easily distracted from reading. They often feel that reading while trying to process its meaning exhaust pupils. Thus, efforts must be taken to revamp educational policy and practices to encourage their reading skills. One of the potential strategies to stimulate reading is through the integration of Interactive Whiteboard in classroom during the instruction of reading comprehension.

\section{Interactive Whiteboard (IWB) As A Tool in Teaching Reading Comprehension}

Interactive Whiteboard (IWB) is an important teaching tool which facilitates pupils in reading comprehension lessons. According to H. J. Smith et al. (2005), IWB comprised of a large, touchsensitive board which is controlled by a computer connected to a digital projector. The integration of IWB and its software in classroom enables teachers to create electronic teaching activities including manipulation of texts and images to increase pupils' understanding (Sorden, 2012).

IWB act as alternative teaching tool for reading comprehension lessons. Activities such as manipulating reading text, and generating digital reading activities using templates, images and other multimedia elements IWB software can be an alternative to traditional learning in which teachers take full responsibility for instructional activities. In contrast, IWB encourages pupils' active and prolonged participation and anticipation for maximum learning to take place.

Integration of IWB helps to create interactive classroom teaching for pupils of all level (Smith et al., 2006). Similarly, Wallace (2007) proposed that IWB strengthens the relationship among pupils and learning subject through simulation graphics. Besides, the smart tools and features built in the IWB enable teachers to highlight text with attractive colours or magnifying reading text to enhance the appearance for visually appealing presentation. Integrating IWB also develops "theatrical tension" in the classroom thus, creating an attractive learning atmosphere 
INTERNATIONAL JOURNAL OF ACADEMIC RESEARCH IN BUSINESS AND SOCIAL SCIENCES Vol. 10, No. 2, Feb, 2020, E-ISSN: 2222-6990 @ 2020 HRMARS

Le Breuilly (2004) stated that integration of IWB creates "electronic magic" within the classroom. Teachers could allow pupils to draw the image and characters from a reading text on the IWB to assist in reading comprehension. This activity tends to increase pupils' self-confidence and cognitive skills. Martin (2010) reported that IWB can be integrated for sequencing practices and provide opportunity for pupils to predict outcome of a story. Moreover, using online quizzes to answer reading comprehension questions with animation and colourful pictures as the positive feedback shall develop pupils' intrinsic motivation to learn.

According to Hall \& Higgins (2005), the interactivity of IWB enhances pupils' interest to learn by presenting a variety of multimedia elements especially visual image. Elliot (2003) stated that IWB enables smooth transition from one topic to another. IWB also improves peer reading and improve communications between pupils and teachers (Yunus et al., 2012).As a presentation tool, IWB creates a dynamic and multi-faceted instruction which enhances pupils' opportunities to learn complex ideas (Glover \& Miller, 2001). The software of IWB allows teachers to vary their presentation methods for a more efficient instruction.

\section{Theoretical Framework \\ Gardner's Theory of Multiple Intelligence}

According to Gardner's Theory of Multiple Intelligence, every human possesses distinctive blend of abilities and skills which reflects on their intelligence and self-potential. As such, this model is commonly used to understand individuals' overall character, preferences and fortes. Gardner's Theory of Multiple Intelligence also posits that learning styles varies among individuals. Thus, they acquire, recall, accomplish, and comprehend in different manner (Wah \& Mohamad, 2018). Although it is a difficult task to fulfil all learning style needs in a single instructional session, yet the role of ICT and multimedia may allow this to happen. As the teachers start to comprehend pupils' learning styles deeply, they could easily create effective learning contents and environment.

\section{Technology Acceptance Model (TAM)}

TAM model is used to describe the adoption and practicality of a new technological tool (Wichadee \& Bogart, 2015). Hence, it can be used to explain the acceptance of teachers and pupils towards IWB technology in ESL classroom. Davis proposed three factors which affect users' acceptance towards utilizing a particular technology; Perceived Usefulness (PU), Perceived Ease of Use (PEOU) and Attitude Toward Usage (ATU) (Davis 1989). This model has a direct relationship to the integration of IWB in ESL classroom. PEOU refers teachers perception on how easy it is to integrate IWB during lessons (Venkatesh \& Davis, n.d.). PU is defined as the teachers' belief that IWB will improve their teaching performances (Lee \& Lee, 2008), while ATU refers to behavioural intention of teachers to integrate IWB in their lessons (Nov \& Ye, 2008).

Teachers' PEOU has significant influence on PU of a technology in the classroom (Shroff et al., 2011). Similarly, PEOU has significant influence on ATU of the teachers (Chang et al., 2012). PU, on the other hand, determines intention to use a technology (Liu et al., 2005). Moss et al. (2007) believes that the integration of IWB allow teachers to be up-to-date with current trends in ESL instruction. IWB improves teachers' ability to provide effective learning avenue for students which can positively influence their interest, concentration, enjoyment and participation (Manny-lkan et al., 2017). 
INTERNATIONAL JOURNAL OF ACADEMIC RESEARCH IN BUSINESS AND SOCIAL SCIENCES

Vol. 10, No. 2, Feb, 2020, E-ISSN: 2222-6990 @ 2020 HRMARS

\section{Methodology}

\section{Research Design}

This study employed a qualitative research design with a case study approach. Teacher Individual Interview (ITI) and Pupils Focus Group interview (FGI) were conducted to probe the perceptions of teachers and pupils, respectively, while classroom observation was conducted to observe learning activities in the selected classroom. The researcher's main concern is to inquire the ESL teachers' and pupils of their perceptions on integration of IWB for ESL reading comprehension lessons and methods of IWB implementation in classroom.

\section{Research Samples}

The samples for this study consisted of six pupils from Year 4, 5 and 6; and six ESL teachers who are experienced during integrating IWB during reading comprehension lessons. The teachers and pupils were selected using purposive sampling method.

\section{Research Instrument}

Research instruments used in this study were Individual Teacher Interview (ITI), Pupils Focus Group interview (FGI), Classroom Observation Field Notes (FN) and Document Analysis (DA).

\section{Data Collection Method}

Methods for data collection include ITI, FGI, classroom observation FN and document analysis. ITI was the primary data collection method for this study. Objective of ITI is to probe teachers' perceptions towards integration of IWB in reading comprehension lessons and to identify the methods of IWB implementation. FGI allows researcher to interact with pupils. Objective of FGI was to probe pupils' perceptions towards integration of IWB in reading comprehension lesson. Classroom observation FN allows researcher to observe what occurs in a classroom situation rather than depending on respondents' response. Classroom observations were conducted and documented as field notes and act as a documentation of pupils' activities during the lessons. Document analysis involves interpretation of documents. In this study, the researcher analysed all six teachers' lesson plans on how they implement IWB during reading comprehension lessons in the classrooms.

\section{Data Analysis Procedure}

Qualitative data analysis in this study is conducted in three phases; data transcribing, data coding and data analysis. Transcribing involves systematically and coherently transferring data from audio recording of $\mathrm{ITI}$ and $\mathrm{FGI}$ among samples into textual form. Coding involves categorizing data into themes through rearrangement recoding, restructuring, and interpretation of collected information. In data analysis, comparison and triangulation of data collected from the various tools (transcriptions of interview sessions, observation field notes and teachers' lesson plans) was conducted to establish trends and patterns.

\section{Findings and Discussions Demographic Data}


INTERNATIONAL JOURNAL OF ACADEMIC RESEARCH IN BUSINESS AND SOCIAL SCIENCES

Vol. 10, No. 2, Feb, 2020, E-ISSN: 2222-6990 @ 2020 HRMARS

The participants for this study consisted of one male and five female teachers. The volunteered teachers were aged between 25 to 45 years old, with $90 \%$ of them living in urban areas of Kulai, Johor. All the six of them had Bachelor of Education Teaching of English as a Second Language (B.Ed TESL) degree background and are currently teaching English for Year 4, Year 5, and Year 6 pupils. Five of the teachers had two to nine years of experience in teaching English for primary school pupils, while one of them had 21 years of similar experience.

\section{Teachers' Integration of ICT and Interactive Whiteboard (IWB) in Classroom}

In general, all the teachers admitted that they tried their best to integrate the IWB in classroom. Based on Table 1.0, it was shown that frequency of integrating IWB for English lessons is highly dependent on teachers' ICT competency. ICT competency of the teachers ranged from belowaverage to good; with T5 and T6 who had below-average competency, T1 and T2 who had average competency, while T3 and T4 who had good competency. Most of them were familiar of and are experienced in using Visualiser, Microsoft Word and PowerPoint. T3 and T4 were able to use more complicated tools and software such as ACE PRO and euro Talk, and consequently were able to integrate IWB more frequently in their lessons. T4 and T5 were self-taught ICT users and showed highest frequency in IWB integration for English lessons. T6 showed lowest frequency in integration of IWB, possibly due to poor ICT competency.

Table 1: Teachers' ICT Competency and Frequency of Integrating IWB

\begin{tabular}{|c|c|c|c|}
\hline & $\begin{array}{l}\text { ICT Tool or Software's integrated } \\
\text { during lessons }\end{array}$ & $\begin{array}{l}\text { Frequency of IWB } \\
\text { integration during English } \\
\text { lessons }\end{array}$ & ICT Competency \\
\hline T1 & $\begin{array}{l}\text { Visualiser, Google chrome, } \\
\text { PowerPoint Presentation }\end{array}$ & Once a week & Average \\
\hline T2 & $\begin{array}{l}\text { Youtube videos, CDs installed in } \\
\text { computer, e-dictionary }\end{array}$ & At least twice in a month & Average \\
\hline T3 & $\begin{array}{l}\text { Flipbook, Microsoft } \quad \text { Word/ } \\
\text { Powerpoint, visualiser, euroTalk } \\
\text { (Interactive Language Learning) }\end{array}$ & Once a week & Good \\
\hline T4 & $\begin{array}{l}\text { Language Games, Youtube videos, } \\
\text { visualiser, ACE PRO }\end{array}$ & Every English lesson & Good (Self-taught) \\
\hline T5 & $\begin{array}{l}\text { Microsoft PowerPoint/ Word, } \\
\text { visualiser, }\end{array}$ & Twice a week & $\begin{array}{l}\text { Below average } \\
\text { (self-taught) }\end{array}$ \\
\hline T6 & Visualiser, E-textbooks & Once a month & $\begin{array}{l}\text { Below average } \\
\text { (Unable to } \\
\text { troubleshoot during } \\
\text { technical issues) }\end{array}$ \\
\hline
\end{tabular}

\section{Pupils' Profile}

Six pupils aged between 10 to 12 years old participated in the study. Information on their age, class, English proficiency level and learning styles were gathered from class teachers and yearly academic achievement report. According to Table 2, there were two pupils from Year 4, 5 and 6, 
INTERNATIONAL JOURNAL OF ACADEMIC RESEARCH IN BUSINESS AND SOCIAL SCIENCES Vol. 10, No. 2, Feb, 2020, E-ISSN: 2222-6990 @ 2020 HRMARS

respectively and each of them were from different classrooms. Majority of the pupils had good to moderate English proficiency. Pupils' learning styles were determined using a short online questionnaire. SI and S4 showed visual learning style while S2 and S5 showed auditory learning style. S6 was a kinaesthetic learner while S3 exhibited both kinaesthetic and auditory learner characteristics.

Table 2 : Pupils' English Proficiency and Learning Style

\begin{tabular}{|l|l|l|c|l|}
\hline & Age & Class & $\begin{array}{l}\text { Proficiency Level } \\
\text { (Grade) }\end{array}$ & Learning Style \\
\hline S1 & 10 & 4A & B & $\begin{array}{l}\text { Kinaesthetic : 30\% } \\
\text { Auditory : 25\% } \\
\text { Visual : 45\% }\end{array}$ \\
\hline S2 & 10 & 4B & B & $\begin{array}{l}\text { Kinaesthetic : 15\% } \\
\text { Auditory : 50\% } \\
\text { Visual : 35\% }\end{array}$ \\
\hline S3 & 11 & 5A & A & $\begin{array}{l}\text { Kinaesthetic : 35\% } \\
\text { Auditory : 35\% } \\
\text { Visual : 30\% }\end{array}$ \\
\hline S4 & 11 & 5B & B & $\begin{array}{l}\text { Kinaesthetic : 20\% } \\
\text { Auditory : 30\% } \\
\text { Visual : 50\% }\end{array}$ \\
\hline S5 & 12 & $6 A$ & A & $\begin{array}{l}\text { Kinaesthetic : 35\% } \\
\text { Auditory : 40\% } \\
\text { Visual : 25\% }\end{array}$ \\
\hline S6 & 12 & 6B & C & $\begin{array}{l}\text { Kinaesthetic : 40\% } \\
\text { Auditory : 30\% } \\
\text { Visual : 30\% }\end{array}$ \\
\hline
\end{tabular}

\section{Perceptions Towards Integration of IWB During Reading Comprehension Lessons Increase Pupils' Excitement to Learn}

Observation conducted in 5B classroom showed that S1 was jumping on his feet when T1 mentioned that she would switch on the IWB to show a video. On the other hand, ITI question "How do your pupils feel when you integrate IWB in the reading lessons?" produced the following responses from the teachers:

"Ahh...my pupils sometimes start jumping around the class whenever I tell them that I will be using the IWB. Err... I think this shows that they were excited" (T1)

"Some pupils will be over the top and some even begs me to integrate it... haha". (T2)

"My pupils and especially the boys tend to read more excitedly through the IWB screen..." (T5)

In FGI, a few keywords which highlights pupils' excitement, such as "...very excited..." (S1), "...feels very happy and want to read more." (S2), "I feel eager to learn..." (S4) and "I feel motivated to read when watching video." (S4) 
were also shown by the transcriptions. These observation and data reveal that pupils tend to feel more excited about their ESL reading comprehension lesson when there is a shift from non-IWB to IWB integrated instruction, supporting that excitement can positively affect pupils' motivation in learning (Poupore, 2014; Inage et al., 2013).

Krashen's Affective Filter Hypothesis posited that students who are motivated could acquire reading skills faster. However, students' motivation to learn is generally reduced in boring and stressful environments (Lin, 2008). As such, teachers may need to incorporate elements of fun and pleasure to create interesting lessons and also to improve overall learning condition. According to Ravinthra et al., (2017), videos and songs help to increase learners' motivation and engagement during reading lessons. As such, it is believed that integration of IWB in this study had enhanced students' excitement, engagement and motivation to learn during ESL reading comprehension lessons.

\section{Increase Pupils' Classroom Engagement}

Integration of IWB enable teachers to manipulate its software to make language learning more fun, interactive and engaging. ITI question 'Do you think that integrating IWB can help your pupils improve their reading comprehension ability?' produced the following responses from the teachers:

"Yes, I can show the meaning of the reading text via visualizer to all the pupils and they read better when they are involved in hands-on reading activity..." (T6)

"Yes, it helps me to allow pupils to come in front of the class to answer questions and find the meaning of words with ease..." (T2)

During FGI, question, "If you had a choice between using the IWB or paper and pencil, which would you rather use? Why?" produced the following responses:

"I choose Interactive Whiteboard; it is because I can know new words from the e-dictionary and interesting." (S2)

"Emm... For me, using the Interactive Whiteboard have good benefits to me. I can know something that I never know before, and can share with my friends on the board." (S1I) "Interactive Whiteboard. It is more fun because I'm not sleepy in the class during the reading quiz on the board." (S3)

The responses from ITI and FGI clearly indicated teachers' and pupils' preference for lessons with IWB integration. Similarly, observation in Year 4B classroom showed that pupils' participation during ESL reading comprehension lesson improved significantly when the teacher integrated IWB, especially in using the e-dictionary software. Hence, teachers may not only integrate IWB to make their lessons more engaging, but also to help in 'scaffolding' pupils' learning activities through their interaction with features of IWB (Warwick \& Mercer, 2011). 
INTERNATIONAL JOURNAL OF ACADEMIC RESEARCH IN BUSINESS AND SOCIAL SCIENCES Vol. 10, No. 2, Feb, 2020, E-ISSN: 2222-6990 @ 2020 HRMARS

\section{Resourceful Learning Experience}

Integration of IWB on this study had been viewed as a resourceful learning experience as it provide ample opportunities for teachers and pupils in Chinese medium school to learn vocabulary and improve English in their daily life, as per indicated by the following ITI responses:

It's really good and very resourceful when it comes to lesson, for example when I'm conducting the reading lesson I'll introduce the students with new words from the reading text and quickly the pupils will browse through the Internet and find the translation of the English words to Mandarin from Google Translate to understand the meaning." (T4)

"I personally feel IWB is a very powerful tool where during a lesson, if a pupil asks, 'What is this?' I can say, 'Lets' go online to view it instantly, instead of just talking about it." (T5)

Similarly, pupils also felt that IWB is resourceful for learning. This was attributed to the Flipbook software incorporated with IWB, as per indicated by the following FGI response:

"I feel it is good because sometimes I don't bring my textbook, so teacher can open the 'Flipbook' to let me read the textbook through the screen..." (S2)

On the other hand, observation in Year 4A classroom showed that pupils tend to use edictionary software in IWB to comprehend reading text and also audio pronunciation software to learn the pronunciation of complex words. These responses and observation justify the growing popularity of IWB due to its Perceived Usefulness (PU) as mentioned in the Technology Acceptance Model (TAM). In a way, teachers' and pupils' belief IWB is resourceful for ESL learning which may help to expand the utilization of IWB in learning of other subjects and also at higher level of education in future (Lee \& Lee, 2008).

\section{Enhance Independent Learning}

According to Bronkhorst (1997), students tend to be independent learners when their senses are engaged, for instance with music and visuals. A few keywords on 'independent learning' were detected in the following ITI responses:

"...observed my pupils working independently to search for words on the Google translate without my help as well." (T6)

"I like the fact that my pupils can work in groups independently with the help of IWB during the reading comprehension quiz..." (T4)

FGI also demonstrated that pupils could confidently engage themselves in independent learning during the integration of IWB. This is because most of the pupils nowadays have access to personal touch screen devices such as smartphone, tablet or laptop and also Internet connectivity at home, which enabled teachers to assign them with homework and projects that can be integrated to IWB. This improve pupils' independent learning and engagement as well (Piroska, 2011). The following responses illustrate the perceptions of pupils towards integrating technology and smart devices to learn in general.

"...my teacher gives me homework to look for difficult words by using the Google at home and then come back to school and... we need to show to our friends in the IWB screen..." (S3) 
INTERNATIONAL JOURNAL OF ACADEMIC RESEARCH IN BUSINESS AND SOCIAL SCIENCES

Vol. 10, No. 2, Feb, 2020, E-ISSN: 2222-6990 @ 2020 HRMARS

"It is easy for us than for older people because when I get a new smartphone, I just grab it and know how to use it. Like my brother and me at home, whenever there is a new application, we can download it." (S3)

"I use my smartphone most of the time as home to do my school homework." (S4)

"I have an iPad at home and I use it every day at home to do a lot of things." (S5)

"I have my small e-dictionary device which I use to do my school homework as well." (S2)

Observation in Year 5A classroom showed that pupils confidently and independently answered the reading comprehension questions on the IWB screen without guidance from teacher. These findings indicate that pupils could be encouraged to learn independently with IWB integration because as digital natives, they grew up using various smart devices and thus felt at ease using the IWB without assistance from teachers (Gregorcic et al., 2018). In this context, the role of teachers was to facilitate the pupils in using the IWB to find the correct answers during reading comprehension lessons.

\section{Promote Seriousness in Reading}

Reading comprehension skill development is very much dependent upon pupils' seriousness in reading. It is common for some pupils to pretend to read in a group reading exercise, which results in them not comprehending the text accurately. Although IWB is thought to solve this problem, ITI responses showed that teachers have mixed opinion on whether pupils take reading seriously during integration of IWB.

"Yes, they take it more seriously now as they know that reading is very important for them and reading comprehension carries a lot of marks when it comes to their exam" (TI)

"No, my pupils tend to get bored fast... use the visualizer most of the time which made my pupils to lost interest in the middle of the lesson." (T6)

During DFG, the question "Do you take writing lesson more seriously?" produced the following responses which showed that majority of them began to take reading more seriously with integration of IWB:

"I have purpose to read when teacher use Interactive Whiteboard in the class..." (S1)

"Yes, I take reading comprehension more seriously with Interactive Whiteboard..." (S2)

"Firstly, I just read because teacher will scold but when use Interactive Whiteboard, I read more serious because it is fun." (S4)

"Yes, I take the reading lesson seriously to get more better in answering reading comprehension questions and to get better marks in exam." (S5)

"At first, not because I thought reading is not fun but when teacher use PowerPoint presentation, I like it at err... and take it seriously." (S3)

Nevertheless, the positive responses from ITI and FGI do not promise a lasting period of pupils' engagement nor interest in lesson with the integration of IWB. This is because learning itself is an active process, and technology might become outdated and useless over time (Lacina, 2009). Therefore, teachers should come up with a more challenging reading activities rather than just text reading via Visualizer software in the IWB. Instead, they need to be constantly creative and innovative in their lessons in order to sustain pupils' seriousness, engagement and interest in ESL reading comprehension classrooms. 
INTERNATIONAL JOURNAL OF ACADEMIC RESEARCH IN BUSINESS AND SOCIAL SCIENCES

Vol. 10, No. 2, Feb, 2020, E-ISSN: 2222-6990 @ 2020 HRMARS

\section{Perceptions on Improvement in Reading Comprehension Improve Pupils' Pronunciation}

The following responses were received from ITI in regards to teachers' opinion towards integration of IWB to improve pronunciation of pupils:

"I realize my pupils read more smoothly without much assistance in pronunciation when reading through Power Point presentation and pictures..." (T2)

"I found the audio software installed in the Interactive Whiteboard is very helpful during reading text because can correct my pupils' pronunciation errors overtime." (T3)

Similar responses were also gathered from the FGI as following:

"It improved my vocabulary and my pronunciation too." (S2)

"In my opinion, I think that my reading become better and I am more aware about my pronunciation error. (S1)

"I feel like want to read more, before this I, err, lazy to read because scared of wrongly say the words..." (S4)

"Yes, I get more confident to read my essay and share with others without embarrassing of my pronunciation error." (S5)

Pronunciation is an important aspect in second language learning and may affect one's confidence while talking in that language. However, reading comprehension alone is not enough for improvement of pronunciation. Based on findings of this study, integration of IWB in ESL lessons may provide a good solution to this problem. This is because the audio voice software installed in IWB could help to correct pupils' pronunciation and boost their confidence in conversing (Amaro-jiménez, 2003).

\section{Improve Vocabulary Acquisition}

The following responses were gathered from ITI on whether integration of IWB helped to improve vocabulary acquisition among students:

"Err, what I like the most is that my weak pupils improved in terms of their vocabulary skill, because they tend to have the visual interpretation of some words through the pictures and graphics shown in Interactive Whiteboard." (T3)

Yes, it does. Err... I did notice my pupils can read even better in an interactive environment where they are more relaxed." (T3)

"I feel they could understand the meaning of the vocabulary which make them not to be scared of reading as much as they were before." (T3)

"They read more and know more words now when they speak to me, like previously they used to tell me. Teacher, I don't know how to describe this... or How can I say that...? So now, they are able to know more words and less likely to ask me the same question." (T2)

"My pupils were able to comprehend difficult words in paragraphs and also can elaborate to explain the reading text, but to do this I need to put in extra effort by preparing a proper PowerPoint presentation on the topic (T1)

"Err, particular skill, that will be in terms of vocabulary as err, as how I have, I have said just now, and not only that, the students also they have learnt on how to comprehend text better 
INTERNATIONAL JOURNAL OF ACADEMIC RESEARCH IN BUSINESS AND SOCIAL SCIENCES Vol. 10, No. 2, Feb, 2020, E-ISSN: 2222-6990 @ 2020 HRMARS

or how to connect their ideas with the text and how to err, I was also surprised when one of my pupil successfully elaborated the reading text and explained to the classmates." (TI)

Teachers felt that the vocabulary of the pupils had improved with integration of IWB. This is because pupils could read and comprehend variety of texts through IWB; and as they read, they could enrich their vocabulary with difficult and complex words. They were also said to be able to use the newly learnt words in their conversation. It is believed that these were due to the interactivity and visual representation of words which is available in IWB which helped pupils to expand their vocabulary.

Similarly, in FGI, the question "What are the changes you see in your reading?" revealed the following responses from pupils:

"It improved my vocabulary and my pronunciation too." (S2)

"In my opinion, I think that my reading become better and I am more aware about my pronunciation error. (S1)

"I can understand the reading the story better." (S3)

"It helps me to, to know more English words because before this my English is really bad." (S4)

Most of the pupils stated that they could notice changes in their vocabulary acquisition. They claimed that utilization of IWB in ESL lesson helped to improve their vocabulary, pronunciation and reading comprehension skills. Hence, the findings of this study indicate that integration of IWB may help pupils to develop understanding of abstract words and phrases through pictures or videos displayed on the projector screen which allow pupils to perform better during ESL reading comprehension lessons. On the other hand, observation in Year 4A and 4B classrooms showed that 30 out of 36 pupils in the $4 \mathrm{~A}$ class were able to answer WH-questions correctly in their reading comprehension language game while most of the pupils in class 4B successfully completed a sequencing activity on IWB screen in groups based on a text they read. This is due to 'electronic magic' of IWB whereby image and characters from text can be drawn on the IWB to increase pupils' understanding (Le Breuilly, 2004). On overall, findings of this study were in agreement to Phillips (2013) who reported an improvement in students' vocabulary acquisition when smart boards were integrated. Additionally, Yunus et al. (2013) stated that ICT (which could also include IWB) helps to capture students' attention, improve their vocabulary and promote meaningful learning.

\section{Implementation of IWB During Reading Comprehension Lessons Teachers' Method of Integrating IWB}

Based on Table 3, from the six teachers who participated, five teachers integrate IWB for presentation of reading text via Visualizer; two of them integrate IWB to display movies, animation or videos based on the reading materials; three of them played audio materials for reading text and two of the teachers conducted educational language games. 
INTERNATIONAL JOURNAL OF ACADEMIC RESEARCH IN BUSINESS AND SOCIAL SCIENCES

Vol. 10, No. 2, Feb, 2020, E-ISSN: 2222-6990 @ 2020 HRMARS

Table 3: Teachers' method of IWB implementation

\begin{tabular}{|c|l|l|}
\hline Theme & Codes & Interviewee \\
\hline Teachers method of & Presentation & $\mathrm{T} 1, \mathrm{~T} 2, \mathrm{~T} 3, \mathrm{~T} 4, \mathrm{~T} 5$ \\
implementation during \\
$\begin{array}{c}\text { reading comprehension } \\
\text { lessons }\end{array}$ & Whiteboard (features) & $\mathrm{T} 1, \mathrm{~T} 3, \mathrm{~T} 6$ \\
& Movie/Animation/Video & $\mathrm{T} 3, \mathrm{~T} 4$ \\
& Listening Audio & $\mathrm{T} 1, \mathrm{~T} 2, \mathrm{~T} 3$ \\
& Visualiser & $\mathrm{T} 1, \mathrm{~T} 2, \mathrm{~T} 3, \mathrm{~T} 6$ \\
& & $\mathrm{~T} 2, \mathrm{~T} 4$ \\
& Language Games & \\
\hline
\end{tabular}

The following responses were obtained from ITI in terms of IWB integration

"I usually use the visualizer attached to the IWB to show reading text and picture for the lesson. For example, for the topic pollution and I show the picture of open burning to allow pupils to understand...". (T6)

"I use the IWB for two purposes. First for presentation... Second for showing videos related to the reading text...". (T2)

"I usually use the IWB to draw pictures during reading lesson. For example, I draw a furniture on the whiteboard to give meaning to the word 'furniture' from the reading text." (T3)

"I use the IWB for two purposes. First for presentation... Second for videos related to the subject..." (T4)

From ITI, it was evident that most teachers prefer presentation and visualiser method for integrating IWB in ESL reading lessons. On the other hand, observation in Year 6B class showed that two teachers used videos, animation and movie in their reading lesson. In FGI, pupils stated the following to indicate their preference for IWB integration:

"I like to learn reading through watching videos and reading Power Point Presentations but my teacher seldom shows us videos..." (S5)

"Playing language game after reading text is my favourite way of learning through IWB." (S4)

According to Wah \& Mohamad (2018), pupils' minds are unique and thus, they acquire, recall, accomplish and comprehend in different ways. Therefore, teachers must be able to implement IWB in diverse ways to ensure its effective integration in ESL reading lesson. Besides, implementing IWB in a variety of methods would also allow different types of learners to benefit from it.

\section{Implementation of IWB According to Learning Styles}

It is common for second language learners to feel unmotivated and lack of confidence, simply because they are learning other than their own language. Thus, customizing instruction according to the Multiple Intelligence Needs may help to optimize pupils' learning. Proper implementation of IWB with learning activities that are tailored to individual learning style would help to highlight the strength of pupils and help them to fully recognize their potential. 
INTERNATIONAL JOURNAL OF ACADEMIC RESEARCH IN BUSINESS AND SOCIAL SCIENCES

Vol. 10, No. 2, Feb, 2020, E-ISSN: 2222-6990 @ 2020 HRMARS

Table 4: Learning activities with integration of IWB

\begin{tabular}{|c|c|c|c|c|c|c|}
\hline & T1 & T2 & T3 & T4 & T5 & T6 \\
\hline $\begin{array}{l}\text { Visual } \\
\text { learners }\end{array}$ & $\begin{array}{l}\text { Videos } \\
\text { Movies }\end{array}$ & $\begin{array}{l}\text { Pictures } \\
\text { Animation } \\
\text { Videos }\end{array}$ & $\begin{array}{l}\text { Explain } \\
\text { vocabularies } \\
\text { through } \\
\text { pictures }\end{array}$ & $\begin{array}{l}\text { Drawing } \\
\text { pictures } \\
\text { on the } \\
\text { screen } \\
\text { from the } \\
\text { reading } \\
\text { text }\end{array}$ & $\begin{array}{l}\text { Show } \\
\text { graphics or } \\
\text { pictures do } \\
\text { explain } \\
\text { meaning }\end{array}$ & $\begin{array}{l}\text { Show text } \\
\text { in the } \\
\text { form of } \\
\text { mind } \\
\text { maps / } \\
\text { diagrams } \\
\text { through } \\
\text { visualiser }\end{array}$ \\
\hline $\begin{array}{l}\text { Kinaesthetic } \\
\text { learners }\end{array}$ & Role play & Action & $\begin{array}{l}\text { Hands-on } \\
\text { activities }\end{array}$ & $\begin{array}{l}\text { Total } \\
\text { Physical } \\
\text { Response } \\
\text { (TPR) } \\
\end{array}$ & $\begin{array}{l}\text { Group work } \\
\text { Project }\end{array}$ & None \\
\hline $\begin{array}{l}\text { Musical } \\
\text { learners }\end{array}$ & $\begin{array}{l}\text { Songs } \\
\text { videos } \\
\text { from } \\
\text { YouTube }\end{array}$ & Jazz Chant & $\begin{array}{l}\text { Learn } \\
\text { through } \\
\text { songs and } \\
\text { chants }\end{array}$ & $\begin{array}{l}\text { Integrate } \\
\text { music } \\
\text { during } \\
\text { learning } \\
\text { activities }\end{array}$ & $\begin{array}{l}\text { Background } \\
\text { music } \\
\text { audio } \\
\text { during self- } \\
\text { reading } \\
\text { session }\end{array}$ & $\begin{array}{l}\text { Reading } \\
\text { song lyrics }\end{array}$ \\
\hline $\begin{array}{l}\text { Linguistic } \\
\text { learners }\end{array}$ & $\begin{array}{l}\text { Essay } \\
\text { writing } \\
\text { (Microsoft } \\
\text { word) }\end{array}$ & $\begin{array}{l}\text { Word game } \\
\text { PowerPoint } \\
\text { presentation }\end{array}$ & $\begin{array}{l}\text { Language } \\
\text { games } \\
\text { (phonics/ } \\
\text { pronunciation } \\
\text { audio) }\end{array}$ & $\begin{array}{l}\text { Giving } \\
\text { opinions } \\
\text { and } \\
\text { views } \\
\text { based on } \\
\text { the text }\end{array}$ & $\begin{array}{l}\text { Question } \\
\text { and answer } \\
\text { sessions on } \\
\text { the screen }\end{array}$ & $\begin{array}{l}\text { Identifying } \\
\text { meaning } \\
\text { of words } \\
\text { using e- } \\
\text { dictionary }\end{array}$ \\
\hline
\end{tabular}

Based on Table 4, teachers were found integrating IWB via a variety of activities according to different learning styles. The following responses were obtained from ITI in regards to this aspect:

"For visual learners, I usually show them videos or movies, when it comes to kinaesthetic learners, I asked them to perform a role play based on the story in the interactive whiteboard... the musical pupils enjoy my English songs and jazz chant lessons from YouTube. Err... for the linguistic learners I expose them with more sentence and essay writing..." (T1)

"Okay, so for visual learners, I usually show text in the form of mind maps or diagrams through visualiser err... for my musical pupils, I gave them song lyrics as a reading text and umm... for linguistic learners I allow them to identify the meaning of difficult words using the e-dictionary on the Interactive Whiteboard." (T6)

In addition, the following responses given by teachers for the question, "Which type of your learners have developed their reading comprehension ability the most among all four types of 
INTERNATIONAL JOURNAL OF ACADEMIC RESEARCH IN BUSINESS AND SOCIAL SCIENCES Vol. 10, No. 2, Feb, 2020, E-ISSN: 2222-6990 @ 2020 HRMARS

intelligence?" showed that visual learners benefitted the most from utilization of IWB during reading lessons:

"...visual learners, because they understand vocabularies better through seeing pictures from the board." (T3)

"Visual and kinaesthetic learners... they can manipulate the IWB screen and benefit from the interesting visuals." (T2)

"Visual learners... being attracted to illustrations and colourful text." (T1)

"Linguistic learner...enjoy answering and asking questions from the screen." (T5)

"Linguistic learner and kinaesthetic learner... They learn better... a lot of improvement in their task." (T4)

Similarly, pupils who were visual and kinaesthetic learners agreed that they are more interested in reading lessons when teacher utilize IWB in the classroom. The following responses were obtained from FGI:

"I prefer reading text through pictures." (S1-visual learner)

"I like to play language games on the Interactive Whiteboard after reading." (S3-

Kinaesthetic learner)

In addition, observation in Year 6A classroom proved that integration of IWB for classroom activity benefitted both kinaesthetic and visual learners as they get to watch videos (visual) and manipulate the IWB screen (kinaesthetic) to group the Malaysian attractions correctly. According to Lacina (2009), the benefit of utilizing technologies such as IWB in classroom helps teachers to meet the varying learning needs of students and also to better engage them in learning. This is because the application of multimedia such as video, pictures, diagrams and websites in IWB allows pupils with different learning style to be engaged simultaneously in the classrooms. Ironically, this may not be easy with other forms of educational technology.

\section{Conclusion}

It can be concluded from findings of this study that IWB enhanced pupils' ESL reading comprehension skills. Data showed that integration of IWB provided pupils with resourceful learning experience which increased their excitement to learn, enhanced their classroom engagement, encouraged independent learning and promoted seriousness in reading. Integration of IWB also improved pronunciation and vocabulary acquisition among pupils. To conclude Research Question 1 (RQ1), IWB in the classroom enabled teachers to teach reading more effectively and maintain pupils' participation in the classroom. Despite the positive responses, teachers have to understand that learning is an active process, and the duration of pupils' engagement is only for a short period where teachers should come up with more challenging reading activities with the integration of IWB in order to maintain an optimum level of engagement and interest in learning.

Based on the findings for Research Question 2 (RQ2) the usage of a variety of multimedia such as video, pictures, diagrams and websites allowed pupils with different learning style to be engaged with the same central point in the classrooms which was not easy to accomplish with another type of technology. The implementation of IWB reduces learning anxiety among language learners which in return promotes a conducive environment for group work and group discussion in the classroom. Therefore, ongoing preparation for a variety of videos or graphics based on the reading 
INTERNATIONAL JOURNAL OF ACADEMIC RESEARCH IN BUSINESS AND SOCIAL SCIENCES

Vol. 10, No. 2, Feb, 2020, E-ISSN: 2222-6990 @ 2020 HRMARS

comprehension texts will be necessary from teachers so that, pupils' enthusiasm to learn can be sustained during lessons.

\section{Implications}

The implication of the study is that teachers need to be made aware of IWB' potential during the ESL reading lessons in particular since they are still at an initial stage of transmission from the conventional 'chalk and talk' teaching approach to integrating IWB for classroom teaching and learning purposes.

Learners benefitted during reading comprehension with the integration of Interactive Whiteboard as it develops their self-confidence where pupils were able to read in a fun learning environment effectively with the help of software installed in Interactive Whiteboard. One of the aims of the School-Based English Language Curriculum (SBELC) is to enable pupils to collaborate with others to solve problems creatively and innovatively in the real world. Pupils' interactions during class allow them to share ideas where they could collaborate to learn better. This supports the assumption of the Zone of Proximal Development (ZPD) where students can perform their tasks individually when they collaborate with more capable peers who can scaffold and increase their participation in learning.

The role of a $21^{\text {st }}$ Century teacher has changed dramatically where teachers are no longer the sole knowledge provider for the students. Highly trained teachers who understand the importance of interactivity will be the significant factor at increasing not only pupils' achievement but also able to solve the pedagogical problems effortlessly. However, it appears that teachers require additional professional and technological training that includes pedagogical content.

Schools' administration should have a clear vision concerning the Interactive Whiteboard to provide periodical pedagogical support for teachers and sufficient professional courses to raise teachers' skills in integrating Interactive Whiteboard during teaching and learning. Since the IWB is a new technology, initial training is important for at least once per school year. In this age of $21^{\text {st }}$ century learning, new technologies must be integrated only into learning and teaching when driven by pedagogy, rather than technology for technology's sake.

\section{Recommendations}

In addition, the results of the study shed some light on the direction of future research on the topic of social media and language learning. Firstly, this study can be further explored by using other Information and Communication Technologies (ICT) tools which support ESL learning, as this study only integrates Interactive Whiteboard (IWB) in carrying out reading comprehension activities. Future researchers are recommended to choose schools with homogeneous characteristics where studies can be done by comparing different types of schools or schools from different states. Thirdly, the availability of the ICT facilities in school should give teachers opportunities to utilize the IWB tools in the classroom to its fullest. Features of IWB and educational software should be included during the in-training preparations to allow the new generation of teachers to be equipped with knowledge on how to harness the potential of during the $21^{\text {st }}$ Century classroom teaching. Fourthly, the study should be explored through a qualitative paradigm by expanding the number of respondents. The use of quantitative method could be applied for a bigger sample size to gain significant findings. 
INTERNATIONAL JOURNAL OF ACADEMIC RESEARCH IN BUSINESS AND SOCIAL SCIENCES Vol. 10, No. 2, Feb, 2020, E-ISSN: 2222-6990 @ 2020 HRMARS

Finally, this study has the potential to be expanded on areas of other language skills such as integrating and implanting the IWB system during writing, speaking or listening skills. Therefore, future researchers could look into this need because without the use of technology in a classroom, students will not prepare for their future as educators would like them to prepare. Students can thrive in an interactive environment if it is differentiated, captivating, and each individual contributes to their role. Consequently, teachers of the $21^{\text {st }}$ century should be able to adapt to changes and new technologies because it is the way forward.

\section{Acknowledgements}

First and foremost, I am very grateful to all the people from Faculty of Education, National University of Malaysia for helping me during this research. Besides, my deepest appreciation towards the principal, teachers and students from Sekolah Jenis Kebangsaan Pei Cheng, Kulai, Johor for their willingness to participate in this research. I am thankful with their warmth support and this study would not be possibly completed without them. Lastly, I wish to express my gratitude to my beloved parents and family members for their understanding, encouragement and endless support.

\section{Corresponding Author}

Maslawati Mohamad, Senior Lecturer, Faculty of Education, National University of Malaysia, 43650 Bangi, Selangor, Malaysia

Email: maslawati@ukm.edu.my; maslawatimohamad@yahoo.com

\section{References}

Alyousef, H. S. (2005). Teaching reading comprehension to ESL learners. The Reading Matrix, 5(1), 143-154.

Alzgool, M. (2019). Nexus between green HRM and green management towards fostering green values. Management Science Letters, 9(12), 2073-2082.

Amaro-Jiménez, C. (2003). Interactive Whiteboards : All-in-one Tool for ESL Teaching and Learning, 2331-2337.

Chang, C., Yan, C., \& Tseng, J. (2012). Perceived Convenience in An Extended Technology Acceptance Model: Mobile Technology and English Learning for College Students. Australasian. Journal of Educational Technology, 28(5), 809-826.

Davis, F. D. (1989). Perceived Usefulness, Perceived Ease of Use, and User Acceptance of Information Technology. MIS Quarterly, 13(3), 319-340.

Elliot, C. (2003). Using a Personal Response System in Economics Teaching. International Review of Economics Education, 1(1), 80-86.

Glover, D., \& Miller, D. (2001). Running With Technology: The Pedagogic Impact of The Large-Scale Introduction of Interactive Whiteboards in One Secondary School. Journal of Information

Technology for Teacher Education, 10(3), 257-

278.https://doi.org/10.1080/14759390100200115

Gregorcic, B., Etkina, E., \& Planinsic, G. (2018). A New Way of Using the Interactive Whiteboard in a High School Physics Classroom: A Case Study. Research in Science Education, 48(2), 465-489. https://doi.org/10.1007/s11165-016-9576-0

Hall, I., and Higgins, S. (2005). Primary School Students' Perceptions of Interactive Whiteboards. 
INTERNATIONAL JOURNAL OF ACADEMIC RESEARCH IN BUSINESS AND SOCIAL SCIENCES

Vol. 10, No. 2, Feb, 2020, E-ISSN: 2222-6990 @ 2020 HRMARS

Journal of Computer Assisted Learning, 21, 102-117.

Inage, I., Lawn, E., \& Lawn, M. (2013). An Analysis of Student Motivation in an ESL Classroom by

Using a Movie and Reader's Theatre Styled Assignments Based on Student Feedback.

Klingner, J. K., Vaughn, S., \& Boardman, A. (2007). Teaching Reading Comprehension to Students With Learning Difficulties. Guilford Press.

Khalid, N., Islam, D. M. Z., \& Ahmed, M. R. M. (2019). SENTREPRENEURIAL TRAINING AND ORGANIZATIONAL PERFORMANCE: IMPLICATIONS FOR FUTURE. Humanities \& Social Sciences Reviews, 7(2), 590-593.

Lacina, J. (2009). Interactive Whiteboards: Creating Higher-Level, Technological Thinkers? Childhood Education, 84(4), 270-275.

Le Breuilly, M. (2004). Benefits of The Interactive Whiteboard. Primary English Magazine, 9(5), 2528.

Lee, J. K., \& Lee, W. K. (2008). The Relationship of e-Learner's Self-regulatory efficacy And Perception Of E-learning Environmental QuOality. Computers in Human Behavior, 24(1), 32-47. https://doi.org/10.1016/j.chb.2006.12.001

Lin, G. H. C. (2008). Pedagogies Proving Krashen's Theory of Affective Filter. Hwa Kang Journal of English Language \& Literature, (14), 113-131.

Liu, S., Liao, H., \& Peng, C. (2005). Applying The Technology Acceptance Model And Flow Theory To Online E-learning. Issues in Information Systems, 6(2), 175-181.

Manny-Ikan, E., Dagan, O., Berger Tikochinski, T., \& Zorman, R. (2017). Using The Interactive White Board In Teaching And Learning - An Evaluation of the Smart Classroom Pilot Project. Interdisciplinary Journal of E-Skills and Lifelong Learning, 7, 249-273. https://doi.org/10.28945/1523

Martin, A. (2010). Analyzing The Impact Of The Interactive Whiteboard on Reading Comprehension.

Moss, G., Jewitt, C., Levacic, R., Armstrong, V., Cardini, A., \& Castle, F. (2007). The Interactive Whiteboards, Pedagogy and Pupil Performance Evaluation: An Evaluation Of The School's Whiteboard Expansion (SWE) Project: London Challenge. University of Lon-Don, Institute of Education, School of Educational Foundations and Policy Studies. Research Report No 816. Retrieved from http://www.dcsf.gov.uk

Nov, O., \& Ye, C. (2008). Users' Personality And Perceived Ease of Use of Digital Libraries: The Case for Resistance to Change. Journal of the American Society for Information Science and Technology, 59(5), 845-851.

Phillips, M. G. (2013). Using The Keyword Method And The Smartboard in Vocabulary Instruction for Students With Learning Disabilities. Master of Arts Dissertation. Rowan University.

Piroska, B. (2011). Students and The Interactive Whiteboard. Retrieved from https://www.researchgate.net/publication/279955708_Students_And_The_Interactive_White board

Poupore, G. (2014). CJAL* RCLA Poupore The Influence of Content on Adult L2 Learners' Task Motivation: An Interest Theory Perspective. The Canadian Journal of Applied Linguistics (Vol. 17).

Rahman, I., \& Jameel, A. (2011). Textual Reading Comprehension Among The EFL Learners. Theory and Practice in Language Studies, 1(10), 1404-1407.

Ravinthra, P., Mohamad, M., \& Yamat, H. (2017). The Effects of Movies on the Affective Filter and 
INTERNATIONAL JOURNAL OF ACADEMIC RESEARCH IN BUSINESS AND SOCIAL SCIENCES

Vol. 10, No. 2, Feb, 2020, E-ISSN: 2222-6990 @ 2020 HRMARS

English Acquisition of Low-Achieving English Learners 8: 1357-1378.

doi:10.4236/ce.2017.88096https://doi.org/10.4304/tpls.1.10.1404-1407

Ghanaguru, S., Liang, H. N., \& Kit, L. N. (2003). An Initial Study Of Reading Problems And Strategies:

A Teacher's Perspective. Retrieved from

http://www.ipbl.edu.my/portal/penyelidikan/seminarpapers/2003/sharminilPBAkk.pdf

Shroff, R. H., Deneen, C. D., \& Ng, E. M. W. (2011). Analysis of The Technology Acceptance Model In Examining Students' Behavioural Intention To Use An E- Portfolio System. Australasian Journal of Educational Technology, 27(4), 600-618.

Simin, G., \& Sani, M. I. (2015). Effectiveness Of ICT Integration In Malaysian Schools: A Quantitative Analysis. International Research Journal for Quality in Education, 2(8), 12.

Smith, F., Hardman, F., \& Higgins, S. (2006). The Impact Of Interactive Whiteboards On TeacherPupil Inter-action In The National Literacy And Numeracy Strategies. British Educational Research Journal, 32(3), 443-457.

Smith, H. J., Higgins, S., Wall, K., \& Miller, J. (2005). Interactive Whiteboards: Boon Or Bandwagon? A Critical Review Of The Literature. Journal of Computer Assisted Learning, 21(2), 91-101. https://doi.org/10.1111/j.1365-2729.2005.00117.x

Sorden, S. (2012). Emerging Trends In Foreign Language Teaching With Information And Communication Technologies. Retrieved from http://www.slideshare.net/ssorden/emergingtrends-in-foreign-language-teaching-with-ict

Umrani, W., Ahmed, U., \& Memon, P. (2015). Examining the absorptive capacity construct: A validation study in the Pakistani banking context. Management Science Letters, 5(12), 10531058.

Venkatesh, V., \& Davis, F. D. (n.d.). A Theoretical Tension Of The Technology Acceptance Model: Four Longitudinal Field Studies. Management Science, 46(2), 186-204. https://doi.org/doi:10.1287/mnsc.46.2.186.11926.

Wah, W. K., \& Mohamad, M. (2018). Pupils' Perceptions Towards The Usage Of Interactive Whiteboard In English As A Second Language Primary Classroom, 10.

Wallace, A. (2007). Do IWBs Have A Future In The UK Classroom? London, UK.: Promethean/Futurelab Debate.

Warwick, P., \& Mercer, N. (2011). Using The Interactive Whiteboard To Scaffold Pupils' Learning Of Science In Collaborative Group Activity, Faculty of Education, University of Cambridge. Development, 1-26.

Wichadee, S., \& Bogart, W. Van De. (2015). View of Exploring Students' Intention To Use LINE For Academic Purposes Based On Technology Acceptance Model. International Review of Research in Open and Distributed Learning, 16(3). Retrieved from http://www.irrodl.org/index.php/irrodl/article/view/1894/3383

Yunus, M. M., Salehi, H., \& Chenzi, C. (2012). Integrating Social Networking Tools into ESL Writing Classroom: Strengths and Weaknesses. English Language Teaching, 5(8), 42-48. https://doi.org/doi:10.5539/elt.v5n8p42.

Yunus, M., Nordin, N., Salehi, H., Embi, M. A., \& Salehi, Z. (2013). The Use Of Information And Communication Technology ( ICT ) In Teaching ESL Writing Skills, 6(7), 1-8.

https://doi.org/10.5539/elt.v6n7p1 
INTERNATIONAL JOURNAL OF ACADEMIC RESEARCH IN BUSINESS AND SOCIAL SCIENCES Vol. 10, No. 2, Feb, 2020, E-ISSN: 2222-6990 @ 2020 HRMARS

Zin, M. L. M., \& Ibrahim, H. (2020). The Influence of Entrepreneurial Supports on Business Performance among Rural Entrepreneurs. Annals of Contemporary Developments in Management \& HR (ACDMHR), 2(1), 31-41. 